Division of Geological \& Geophysical Surveys

PRELIMINARY INTERPRETIVE REPORT 2005-6

\title{
OIL AND GAS SEEPS OF THE PUALE BAY - BECHAROF LAKE - WIDE BAY REGION, NORTHERN ALASKA PENINSULA
}

by

Robert B. Blodgett and Karen H. Clautice

September 2005

THIS REPORT HAS NOT BEEN REVIEWED FOR TECHNICAL CONTENT (EXCEPT AS NOTED IN TEXT) OR FOR CONFORMITY TO THE EDITORIAL STANDARDS OF DGGS.

Released by

STATE OF ALASKA

DEPARTMENT OF NATURAL RESOURCES

Division of Geological \& Geophysical Surveys

3354 College Rd.

Fairbanks, Alaska 99709-3707

$\$ 10.00$ 



\title{
OIL AND GAS SEEPS OF THE PUALE BAY - BECHAROF LAKE - WIDE BAY REGION, NORTHERN ALASKA PENINSULA
}

\author{
Robert B. Blodgett $^{1}$ and Karen H. Clautice ${ }^{2}$
}

The east side of the northern Alaska Peninsula near Puale Bay (formerly known as "Cold Bay"3) and the Iniskin Peninsula of Lower Cook Inlet have long held interest to exploration geologists due to their well developed oil and gas seeps, which spurred on the first active exploration and drilling efforts for petroleum in Alaska. Several oil rushes occurred in the early part of $20^{\text {th }}$ century, primarily in two phases (1902-1905 and 1922-1926) in the area of Puale Bay and Becharof Lake (fig. 1). Unfortunately all of these wells produced only traces of hydrocarbons. Several subsequent deeper wells were drilled in Mesozoic strata of this region and nearby Wide Bay to the south, but like the earlier efforts, did not prove to be economical.

In light of the upcoming oil and gas lease sale in the Bristol Bay region October 26, 2005, the Alaska Division of Geological \& Geophysical Surveys (DGGS) is undertaking an assessment of possible oil- and gas-bearing rocks on the Alaska Peninsula (Reifenstuhl and others, 2004 and 2005; Finzel and others, 2005; Blodgett, in preparation). DGGS's efforts are supported in part by the Alaska Energy Technology Development Laboratory through the U.S. Department of Energy and by the Bristol Bay Native Corporation. Due to the renewed interest in this region, it was deemed necessary to compile a detailed listing of all proven oil and gas seeps in the area of Puale Bay, Becharof Lake, and Wide Bay, and plot their occurrences on a modern map base for use by petroleum explorationists. All of these seeps are developed in Middle and Upper Jurassic strata belonging to Kialagvik, Shelikof, and Naknek formations. Each oil and gas seep from this region is plotted on the map accompanying this report and their coordinates are listed in table 1 . The DGGS field party visited and sampled only the seep at locality 4 during the 2004 and 2005 field seasons (Reifenstuhl and others, 2005). The seep at locality 5 was also visited briefly, but was not sampled. It must be stressed that localities and coordinates listed herein were often determined from primitive map bases, and thus are often only approximate, due to the primitive nature of the earlier topographic maps used in the 1920s. The type of location information used is noted with each occurrence. Original published information concerning the seeps is reproduced below. In addition, a single prominent solid hydrocarbon locality cited in the early literature is also discussed here. Geochemical data is given for the seeps visited by Blasko (1976a) and for the main oil seep along Oil Creek (locality 4 herein) in Reifenstuhl and others (2005) and Magoon and Anders (1992). See Detterman and others (1987) and Riehle and others (1993) for the most recent geologic mapping compilations related to the region discussed in this report.

The references cited at the end of this report are those used in this compilation of known oil and gas seeps in the area of Puale Bay, Becharof Lake and Wide Bay on the Alaska Peninsula. In addition to these references, research was also done into the original field notes and field maps of the various investigators, as well as industry data (in the form of maps) derived from the early exploratory efforts conducted in the region between 1902-1905 and 1922-1926 and subsequently donated to the U.S. Geological Survey.

\footnotetext{
${ }^{1} 629$ O Street, \#203, Anchorage, Alaska 99501

${ }^{2}$ Alaska Division of Geological \& Geophysical Surveys, 3354 College Road, Fairbanks, Alaska 99709

${ }^{3}$ Not to be confused with the town of Cold Bay more than 300 miles to the southwest along the Alaska Peninsula.
} 


\section{MT. KATMAI A-5 QUADRANGLE \\ Gas seepage in Naknek Formation}

Location: 1

Reference: Smith, 1925, p. 206

Numerous gas seepages occur "for about 200 yards along the stream and issue from the loose boulders in its bed. The gas has a very faint odor, is colorless, and burns with a bright yellow flame."

Approximate location plotted from primitive topographic map shown in Plate 4 of Smith (1925).

Note that a photo (fig. 1) exists in USGS archives showing the USGS field party led by W.R. Smith cooking their food with gas from this seep in 1923. The seeps are in the Naknek Formation.

\section{KARLUK D-5 QUADRANGLE Gas seepage in Naknek Formation}

Location: 2

Reference: Smith and Baker, 1924, p. 206

"A gas seepage was seen near the head of the East Fork of the Kejulik River. The gas emerges at two places several hundred feet apart, both at the foot of a bluff on the edge of a narrow valley. The gas flows in a nearly continuous stream of bubbles and has built up a low mound around the orifice. Evidently considerable water is emitted with the gas, as the mound is composed of a soft mud surrounded by an otherwise dry valley floor and a small stream of water flows away from the seepage. The rocks forming the bluff along the edge of the valley and underlying the valley belong to the lower part of the Naknek formation.”

[Note: No map location given in Smith and Baker (1924), but presumably it is the same locality indicated below in Blasko, 1976a]

Reference: Blasko, 1976a, p. 41

"A significant gas seep was located and sampled on the East Fork of the Kejulik River (fig. 5). This seep is notable because the analysis indicates a relatively high Btu value. The seep itself was located on the north side of the main stream, a 6-foot-diameter water pool with gas and water was obtained from the location ..."

[Location of seep shown in fig. 5 of Blasko, 1976a] 


\section{KARLUK C-6 QUADRANGLE \\ (BEAR CREEK-SALMON CREEK ANTICLINE - EAST FIELD)}

\section{Oil seepages in Shelikof Formation on Oil Creek}

Locations: 3, 4, 5 [3 is seep B of Blasko, 1976a; 4 is seep A of Blasko, 1976a; and 5 is small seepage emerging from a fractured sandstone outcrop of the Shelikof Formation downstream along Oil Creek from location 4. See figs. 2 and 3 for photos of seeps at localities 4 and 5, respectively]

Reference: Capps (1922, p. 107)

"The most frequently visited seepages are those on the head of Oil Creek, about 5 miles west of Cold Bay. Here the largest seepage emerges from a smooth vegetation-covered slope in which no rock outcrops can be seen. The oil, accompanied by an abundant flow of water and considerable gas, bubbles forth as a strong spring, the surface of which is coated with a thick layer of brown oil. A rough estimate placed the volume of the oil flow at about half a barrel a day. The gas flows by heads and is of sufficient volume to support a strong flame for several seconds at a time. From this seepage the escaping water and oil flow down a long grassy slope in which most of the oil is entrapped. Similar conditions have existed for a long time, with the result of building up a large area of the less volatile paraffin residue of the oil, which has now hardened to a stiff, puttylike consistency. This residue, intimately intermixed with vegetation, covers an irregular but roughly triangular area, the base of which is 450 feet across and the long sides about 600 feet, in which the residue is from 1 to 6 feet thick. ..... A short distance below the Oil Creek residue patch a number of oil seepages emerge from Shelikof sandstone along the banks of Oil Creek. The quantities of oil emerging are small,...”

[see Plate 2 for location]

Reference: Smith and Baker (1924, p. 205)

"The largest seepage is found at the head of Oil Creek, in the East field, where oil, gas, and water emerge as a strong spring and the evaporation of the more volatile constituents of the oil has left a large area of viscous black residue 1 to 6 feet thick. The flow of this seepage was estimated by Capps at about half a barrel a day. On Oil Creek below the residue patch there are several seepages that yield a small flow of oil.”

Reference: (Blasko, 1976a, p. 41)

"The oil and gas seeps at the head of Oil Creek (fig. 4) are the most prolific of those observed on the Alaska Peninsula. Oil and gas issue from two separate springs situated at the foot of a small knoll on the southern side of Oil Creek." 
Ibid, p. 48 - "Seep A (fig. 4) was found in a water-oil pond about 18 inches in diameter and 5 inches deep, which bubbled intermittently but constantly. A frothy oil covered the seep area. The water and oil from this seep flow into a pond about 20 feet by 40 feet. .... Gas bubbling up through the seep burst into flame when lit with match. The flame is sustained as long as the emission is constant." [Note this was the classic seep the DGGS party visited and filmed in 2004 - see Fig. 2 for photograph]

Ibid, p. 48 - "Seep B (fig. 4) was located approximately 45 feet west of seep A. The seep was not a readily discernable as seep $\mathrm{A}$, since it lacked the physical activity of a bubbling spring. The head of the seep area is a series of approximately five small water trickles that cover an area with a radius of 4 feet and collect at one point. ..."

An oil sample collected from location 4 herein, near the head of Oil Creek (Section 10, T29S, R40W), was one of a suite of biodegraded oils analyzed by Magoon and Anders (1992) using carbon isotopic and biomarker techniques. Their isotopic data suggest this suite of oils was sourced from marine source rocks, and the pronounced occurrence of C28 and C29 tricyclic terpanes as well as an unidentified pentacyclic biomarker suggest these oil are co-sourced from the Upper Triassic Kamishak and Middle Jurassic Kialagvik formations. More modern analyses of oil samples collected from the Oil Creek seeps by DGGS geologists in 2004 are underway courtesy of the USGS at the time of this writing (L.B. Magoon, personal communication, 2005). These latest techniques may yield further insight to the relative contribution from these two oilprone sources.

\section{Oil seepage in Shelikof Formation along South Fork of Rex Creek}

Location: 6

Reference: Capps (1922, p. 108)

"A small oil seepage is reported in the valley of South Fork of Rex Creek, and another in a gulch tributary to Bear Creek from the northeast."

[see Plate 2 for location]

Reference: Smith (1926, p. 77-78)

"The seepage in the South Fork of Rex Creek occurs along the South Fork fault in the central part of the valley and issues from sandstone and shale for a distance of 100 feet along the bank of the stream. This seepage is much lower in the section than the seepage on Bear Creek, which is very close to the Island Bay fault, and probably the oil escapes through a fissure connected with the fault. ... the seepage on South Fork is much lower in the section and is known to occur on a fault through which the oil might migrate vertically from a still lower horizon.” 
[see Pl. 4 (facing p. 74) for structure contour map that shows geographic location of Rex Creek seepage, along South Fork fault]

Reference: Blasko (1976a, p. 59)

"Although no noticeable oil or gas seeps were observed on any of the forks or main stream of Rex Creek, a blue-sheened water seep was observed near the south fork of Rex Creek. This seep was sampled, and the creek was sampled near its mouth.”

\section{Oil and gas seepages in Shelikof Formation on Bear Creek}

Locations: 7 (oil seep of Blasko, 1976a), 8 (gas seep of Blasko, 1976a)

Reference: Capps (1922, p. 108)

"A small oil seepage is reported in the valley of South Fork of Rex Creek, and another in a gulch tributary to Bear Creek from the northeast.” [see Plate 2 for location]

Reference: Smith (1926, p. 77)

"The largest seepage on the Salmon Creek-Bear Creek anticline occurs in the valley of Bear Creek. A considerable quantity of oil and residue has collected in a circular pool about 50 feet in diameter with a narrow outlet 120 feet long to Bear Creek.... Thick beds of shale crop out on the south side of the valley opposite the Bear Creek seepage.” [Location of seepage shown in Plate 4]

Reference: Blasko (1976a, p. 59)

"A gas seep was located on Bear Creek downstream from the landing strip that serviced the drilling operations of the Bear Creek No. 1 exploratory well drilled in 1957-59. The seep was vigorous and the bubbles emerging from the base of the water pool were sufficient to ignite a flame despite moderately strong west wind.” [See fig. 4 for location]

Reference: Blasko (1976a, p. 59)

“An oil seep was also located on Bear Creek (fig. 4). The seep covers an area of about 100 feet by 150 feet. There are two separate seep ponds about 60 feet apart. There was no indication that oil was actively being seeped to the surface, although oil scum floated on the surface of the water and clung to the grass along the seep drainage. Occasionally, gas bubbles rose sporadically to the surface through the water." 


\section{Oil seepage in Shelikof Formation on Salmon Creek (note two differing locations indicated by Capps, 1922, and Smith, 1926)}

Locations 9 (oil seep reported by Capps, 1922), 10 (oil seep of Smith, 1926)

Reference: Capps (1922, p. 108)

"On upper Salmon Creek a small quantity of heavy brownish-black oil appears in the stream gravels a short distance from the sandstone bluffs that border the stream flat."

[see Plate 2 for location]

Reference: Smith (1926, p. 77)

"A larger seepage issues through the alluvium in the main valley of Salmon Creek about 11/2 miles southwest of the axis of the anticline .... The rocks exposed close to the seepage in the main valley consist of sandstone, fine conglomerate, and thin beds of shale.” [Location of seepage shown in $\mathrm{Pl}$. 4]

Reference: Blasko (1976a, p. 59)

"No active discernable oil or gas seeps were observed on Salmon Creek (fig. 4). However, a sample of gas was obtained from a pool of water surrounding the surface casing of a plugged and abandoned well near the head of Salmon Creek. The emerging gas bubbles would not ignite.”

\section{UGASHIK C-1 QUADRANGLE PEARL CREEK DOME (WEST FIELD)}

\section{Oil seepage and residue patch \# 1 in Naknek Formation on Little Ugashik Creek (Barabara Creek of older maps)}

Location: 11

Reference: Capps (1922, p. 108)

"On the north side of Barabara Creek [Note: this is Little Ugashik Creek of present-day USGS 1:63,360-scale topographic map], near its mouth, is a large patch of residue similar in size and character to that on the head of Oil Creek. The point of emergence of the oil, of which the residue constitutes the less volative remainder, was in a small tributary gulch, and from that point the residue extends down the gulch and out into the main valley a distance of about 1,200 feet, covering an area of about 1 acre. Its thickness was not determined but is doubtless irregular, being influenced by the irregularities of the surface on which it has accumulated. A small drainage line that runs through the residue contains depressions in which the water is covered with thick dark-brown oil, but no point could be located from which the oil could be seen 
emerging. This residue is somewhat softer than that on Oil Creek and like it contains a large percentage of vegetable matter as an impurity.” [see Plate 2 for location]

Reference: Smith and Baker (1924, p. 205-206)

"Two residue patches occur on the Pearl Creek dome. One near the mouth of Barabara Creek on its north side is similar in size and character to the patch on Oil Creek. The actual point of emergence of the oil could not be seen, but water running along a drainage line through the residue was covered with thick dark-brown oil."

Reference: Smith (1926, p. 86-87)

"Several oil seepages and two patches of residue occur on Pearl Creek dome. The largest seepage and patch occur about 1 mile upstream from the mouth of Barabara Creek [Note: This is Little Ugashik Creek of present-day USGS 1:63,360-scale topographic map]. The residue has been successfully used as fuel for drilling. A pit 12 feet deep does not reach the bottom of the deposit. ... The opposite side of the valley of Barabara Creek have been displaced at least 200 feet by a fault that strikes through the saddle between Mount Demian and Mount Lee. The seepage near the mouth of the creek is in alignment with this fault."

\section{Oil seepage and residue patch \#2 in Naknek Formation on Barbara Creek (Pearl Creek of older maps)}

Location: 12

Reference: Capps (1922, p. 108-109)

"Another small patch of residue on the Pearl Creek dome occurs in the valley of Pearl Creek [Note: this is Barabara Creek of present-day USGS 1:63,360-scale topographic map] about 1 mile northeast of the large patch just described. It has an area of about 3,000 square feet and probably has a maximum thickness of not more than a few feet. The material closely resembles that on Barabara Creek. No oil was seen emerging from the rock, but a thick brown oil in considerable quantities oozes from the residue and flows down the creek. Several other small seepages are reported to occur near the residue but were not seen.”

[see Plate 2 for location]

Reference: Smith and Baker (1924, p. 205-206)

"The other residue patch, which is somewhat smaller, lies in the valley of Pearl Creek about a mile northeast of the large patch. No oil was seen emerging from the rock, but a thick brown oil 
oozes from the residue and flows down the creek. The rocks underlying these two residue patches belong to the lower part of the Naknek formation. Other small seepages have been reported to occur in the valley of Pearl Creek.”

\section{UGASHIK C-2 QUADRANGLE}

Oil seepage in Naknek Formation on Moore Creek

[location only shown approximately, based on written description given in literature]

Location 13

Reference: Smith and Baker, 1924, p. 209

“Oil seepages were reported to occur near the head of Moore Creek, but they were not found by members of Mr. Sargent's party. Along the fault at Moore Creek there are several springs giving off sulphur dioxide gas, which has a very characteristic odor and forms a white scum on the water. After the scum has been in contact with the air for some time it becomes black. The black substance has the appearance of an oil residue, but its physical properties differ, and it can be easily distinguished from oil residue by its peculiar odor and low viscosity. Several pools of water with an iridescent scum of iron oxide, which might be mistaken for oil, were seen in the small valleys in this general locality.”

Reference: Smith, 1926, p. 87

"A small amount of residue occurs in several fissures near the thrust fault in the canyons west of the sharp bend in Moore Creek. An active seepage is reported near this locality. The beds beneath the Moore Creek area should be somewhat similar to those beneath Pearl Creek dome.”

\section{UGASHIK B-1 QUADRANGLE}

\section{Solid hydrocarbon (gilsonite) in Kialagvik Formation at Wide Bay}

Location: 14

Reference: Smith (1926, p. 84-85)

"At several localities on both sides of the bay and in the rocks at the oil seepages a solid hydrocarbon occurs in thin irregular stringers along vertical fault planes and small fissures. In a cliff along the beach about half a mile northeast of Lee's store the stringers had a maximum observed width of 2 inches. Crystals of calcite generally occur along the fissures with the hydrocarbon. No evidence of lateral migration from the fissure was noted. The material ignites easily and emits an odor similar to that of burning residue. An analysis [made by E.T. Erickson, USGS, notes: "Specimens of the sample showed homogeneous structure and subconchoidal fracture with brillant black luster. The powdered sample was dark brown. ... Probably the oil and 
hydrocarbon have a common origin. Two viewpoints regarding the origin of the hydrocarbon may be taken - that it is a residue left after the oil has migrated; or that material which represents an earlier stage in the metamorphism of the petroleum has entered the fault plane.”

Reference: Kellum et al. (1945, p. 16)

"Two oil seepages were reported from the Kialagvik formation on Wide Bay but they were not observed in 1944. A few thin, lenticular streaks of a black, dense, brittle, amorphous substance resembling coal were noted in the sandstone along Wide Bay northwest of Short Creek. The absence of seepages along the faults does not signify that there has been no accumulation of oil in reservoirs beneath the surface."

Reference: Miller et al. (1959, p. 33-34)

"At Wide Bay in the Kanatak district a small oil seep was found in 1924 in sandstone of the Kialagvik formation exposed at low tide in a reef on the northwest flank of the Wide Bay anticline (Smith, 1926, p. 84-85). Smith also observed thin veinlets of a solid hydrocarbon residue resembling gilsonite in the Kialagvik formation at several localities on Wide Bay.”

\section{UGASHIK B-2 QUADRANGLE}

\section{Oil seepage in Kialagvik Formation at Wide Bay}

Location: 15

Reference: Smith (1926, p. 84)

"A small oil seepage was found in the rocks exposed at low tide opposite the mouth of Pass Creek. These rocks consist of light-colored grit and pebbly sandstone that strike S. 45 deg. W. and dip 8-10 deg. NW. and are probably the lowest beds exposed at Wide Bay. The oil issues from cracks in the sandstone. A think coating of residue adhered to the walls of the cracks. Bubbles of gas escaped continuously through the water close to the oil seepage. The gas was not ignited. Only a small amount of oil was seen, but the seepage was active. This is the only seepage known at Wide Bay and is significant in that it proves that oil occurs in Middle Jurassic beds on the Alaska Peninsula as well as near Iniskin Bay, Cook Inlet.”

Reference: Kellum et al. (1945, p. 16)

“Two oil seepages were reported from the Kialagvik formation on Wide Bay but they were not observed in 1944. A few thin, lenticular streaks of a black, dense, brittle, amorphous substance resembling coal were noted in the sandstone along Wide Bay northwest of Short Creek. The 
absence of seepages along the faults does not signify that there has been no accumulation of oil in reservoirs beneath the surface."

Reference: Miller et al. (1959, p. 33-34)

"At Wide Bay in the Kanatak district a small oil seep was found in 1924 in sandstone of the Kialagvik formation exposed at low tide in a reef on the northwest flank of the Wide Bay anticline (Smith, 1926, p. 84-85). Smith also observed thin veinlets of a solid hydrocarbon residue resembling gilsonite in the Kialagvik formation at several localities on Wide Bay.”

\section{ACKNOWLEDGMENTS}

We are grateful to Paul L. Decker, Alaska Division of Oil \& Gas, Anchorage, Alaska, and Robert Swenson, Alaska Division of Geological \& Geophysical Surveys, Fairbanks, Alaska, for their thoughtful review and comments on this manuscript.

\section{REFERENCES ON SEEPS}

(The most critical references are those shown in bold print.)

Becker, P.R., and Manen, C.-A., 1989, Natural Oil seeps in the Alaskan marine environment: U.S. Department of Commerce, National and Oceanic Atmospheric Administration (NOAA), Outer Continental Shelf Environmental Assessment Program, Final Reports, v. 62, p. 1-126.

Blasko, D.P., 1976a, Oil and gas seeps in Alaska. Alaska Peninsula, western Gulf of Alaska: U.S. Bureau of Mines Report of Investigations 8122, 78 p.

Blasko, D.P., 1976b, Occurrences of oil and gas seeps along the Gulf of Alaska: Eighth Annual Offshore Technology Conference, 1976 Proceedings, v. 1, p. 211-220.

Capps, S.R., 1922, The Cold Bay district: U.S. Geological Survey Bulletin 739-C, p. C77C116.

Cronin, M.A., Brannon, M.A., Brannon, E., and Moulton, L., 1999, Natural oil seeps in the Puale Bay area of the Becharof National Wildlife Refuge, and the Blue Creek area of the Alaskan Peninsula National Wildlife Refuge, Alaska: A Report to Refuge Manager, Becharof National Wildlife Refuge, 7 p., 38 figs.

Dall, W.H., 1896, Report on coal and lignite of Alaska, p. 763-908, in Seventeenth Annual Report of the Survey, 1895-1896, Part 1. U.S. Geological Survey.

Johnson, T.C., 1971, Natural oil seeps in or near the marine environment; a literature survey: U.S. Coast Guard Report Project No. 714141/002, 30 p.

Kellum, L.B., Daviess, S.N., and Swinney, C.M., 1945, Geology and oil possibilities of the southwestern part of the Wide Bay anticline, Alaska: U.S. Geological Survey Special Publication, 17 p., 9 pls.

Magoon, L.B., and Anders, D. E., 1992, Oil-to-source-rock correlation using carbon-isotopic data and biological marker compounds, Cook Inlet-Alaska Peninsula, Alaska, p. 241-274, in 
Moldowan, J.M., Albrecht, P., and Philp, R.P., (eds.), Biological markers in sediments \& petroleum: Englewood Cliffs, New Jersey, Prentice Hall, 411 p.

Martin, G.C., 1904, Petroleum fields of Alaska: U.S. Geological Survey Bulletin 225, p. 365382.

Martin, G.C., 1905, The petroleum fields of the Pacific coast of Alaska, with an account of the Bering River coal deposits: U.S. Geological Survey Bulletin 250, 64 p.

Martin, G.C., 1905, Notes on the petroleum fields of Alaska: U.S. Geological Survey Bulletin 259, p. 128-139.

Martin, G.C., 1921, Preliminary report on petroleum in Alaska: U.S. Geological Survey Bulletin 719, 83 p.

McGee, D.L., 1972, Gulf of Alaska petroleum seeps: Alaska Division of Geological \& Geophysical Survey Open-File Report 32, 7 p.

Miller, D.J., Payne, T.G., and Gryc, George, 1959, Geology of possible petroleum provinces in Alaska: U.S. Geological Survey Bulletin 1094, 131 p.

Smith, W.R., 1925, The Cold Bay-Katmai district: U.S. Geological Survey Bulletin 773-D, p. 183-207.

Smith, W.R., 1926, Geology and oil developments of the Cold Bay district, Alaska: U.S. Geological Survey Bulletin 783-C, p. 63-88.

Smith, W.R., and Baker, A.A., 1924, The Cold Bay-Katmai district: U.S. Geological Survey Bulletin 755-D, p. 151-218.

\section{REFERENCES ON THE MOST CURRENT GEOLOGIC MAPPING OF THE STUDY AREA}

Detterman, R.L., Case, J.E., Wilson, F.H., and Yount, M.E., 1987, Geologic map of the Ugashik, Bristol Bay, and western part of the Karluk quadrangles, Alaska: U.S. Geological Survey Miscellaneous Investigations Series Map I-1685, scale 1:250,000.

Riehle, J.R., Detterman, R.L., Yount, M.E., and Miller, J.W., 1993, Geologic map of the Mt. Katmai quadrangle and portions of the Naknek and Afognak quadrangles, Alaska: U.S.

Geological Survey Miscellaneous Investigations Series Map I-2204, 1 sheet, scale 1:250,000.

\section{REFERENCES TO THE CURRENT DGGS WORK IN THIS REGION}

Blodgett, R.B., 2005, Observations on Mesozoic fossils and stratigraphy during field investigations of the northern Alaska Peninsula (Puale Bay, Wide Bay, and Becharof Lake Region) by DGGS/ADOG, May 24-June 4, 2004 (in preparation).

Finzel, E.S., Reifenstuhl, R.R., Decker, P.L., and Ridgway, K.D., 2005, Sedimentology, stratigraphy, and hydrocarbon reservoir-source rock potential, using surface and subsurface data of Tertiary and Mesozoic strata, Bristol Bay Basin and Alaska Peninsula: Alaska Division of Geological \& Geophysical Surveys Preliminary Interpretive Report 2005-4, 67 p.

Reifenstuhl, R.R., Bailey, R.D., and Finzel, E.S., 2005, Bristol Bay and Alaska Peninsula 2004: Fieldwork and sample analyses compilation report: Alaska Division of Geological \& Geophysical Surveys Preliminary Interpretive Report 2005-1, 20 p.

Reifenstuhl, R.R., Shafer, D.C., Ryherd, T.J., Brizzolara, D.W., and Blodgett, R.B., 2004, Summary of May 25-June 4, 2004 field season notes and samples, Puale Bay and Wide Bay areas, Alaska Peninsula: Alaska Division of Geological \& Geophysical Surveys Raw Data File 2004-3, 16 p. 


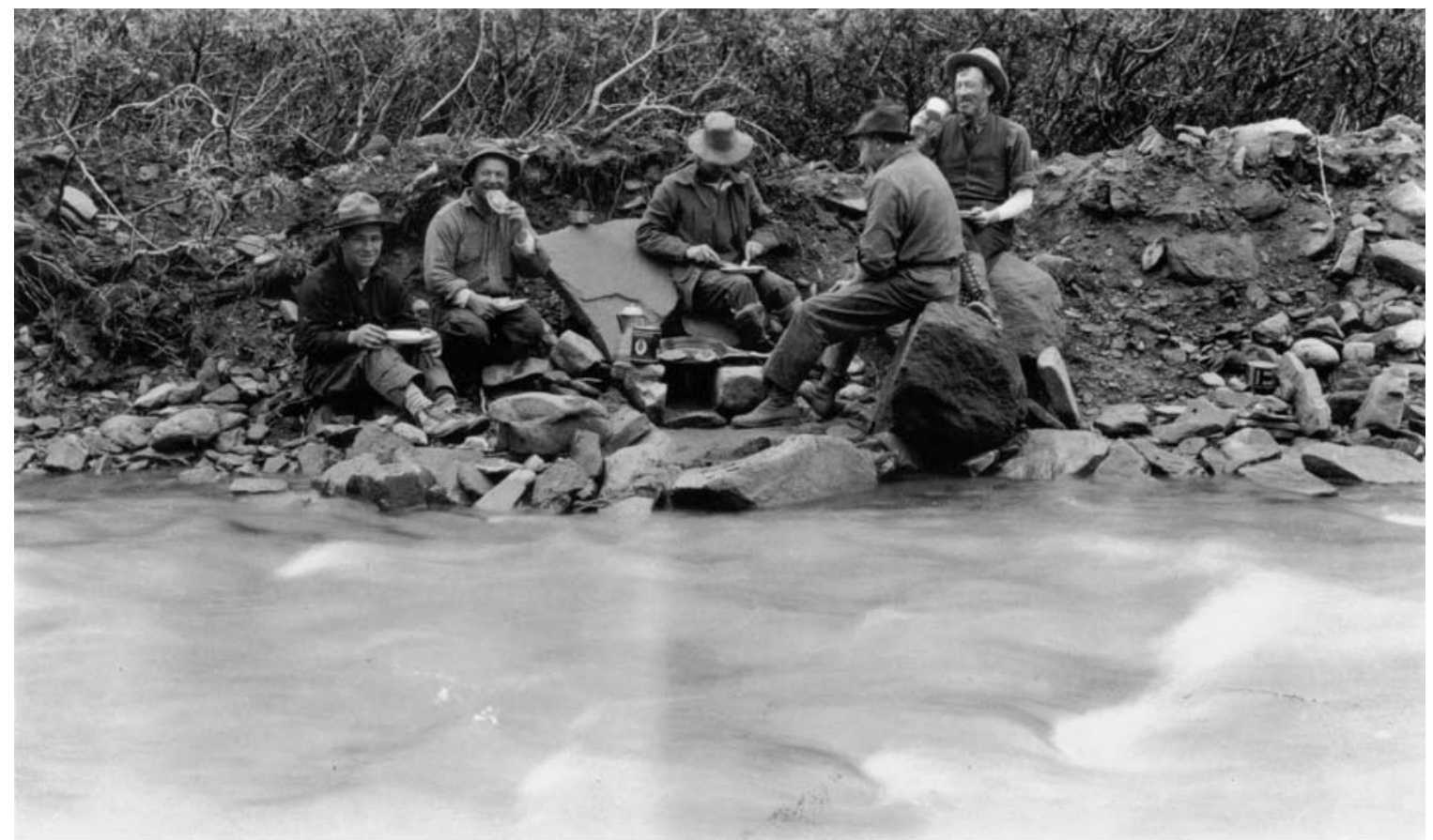

Figure 1. U.S. Geological Survey field party led by W.R. Smith cooking breakfast over natural gas seeps along Gas Creek, summer 1923.

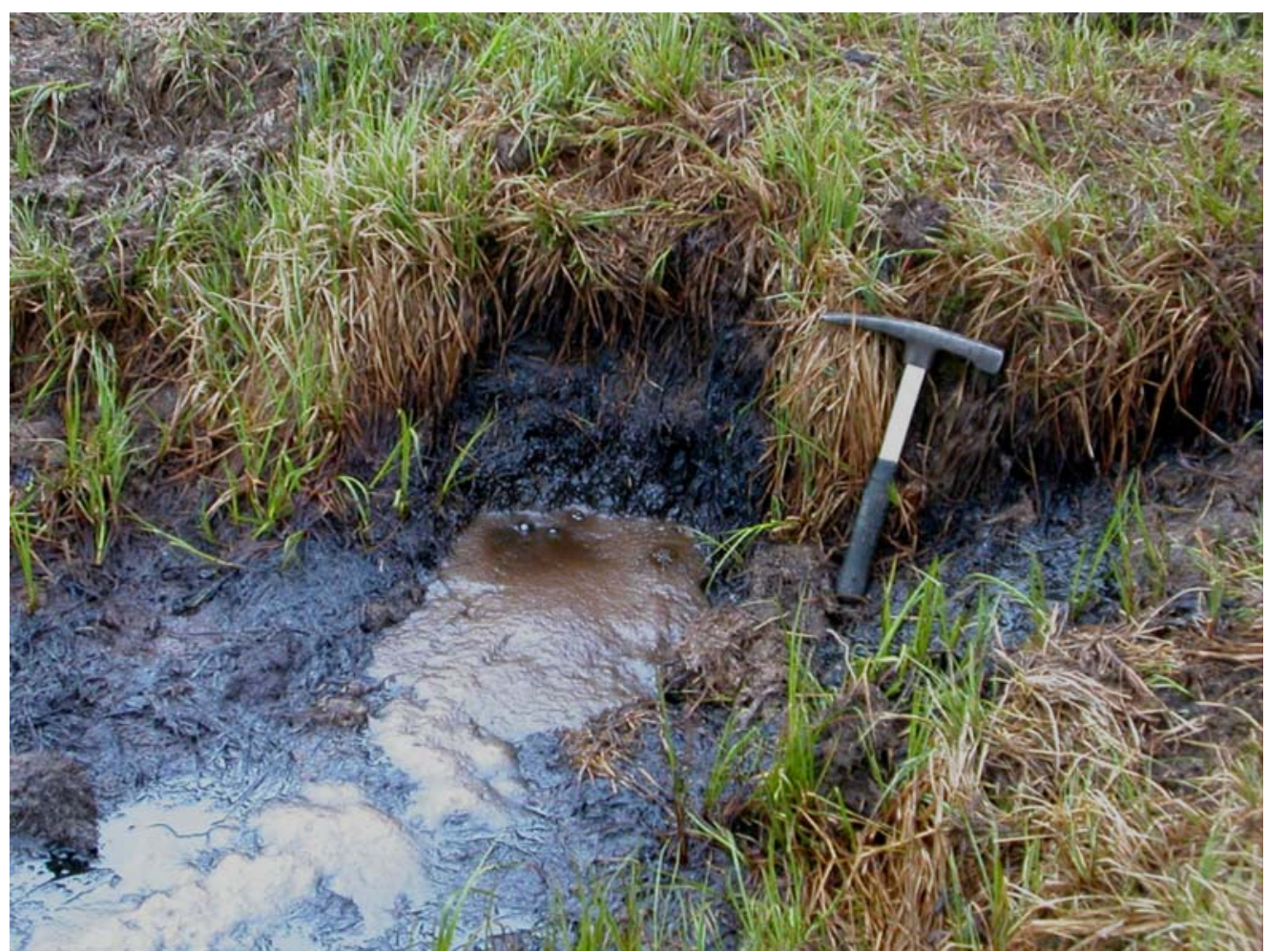

Figure 2. Main oil seep along Oil Creek (location 4 of text). Photo taken May 30, 2004, during visit to site by DGGS field party. 


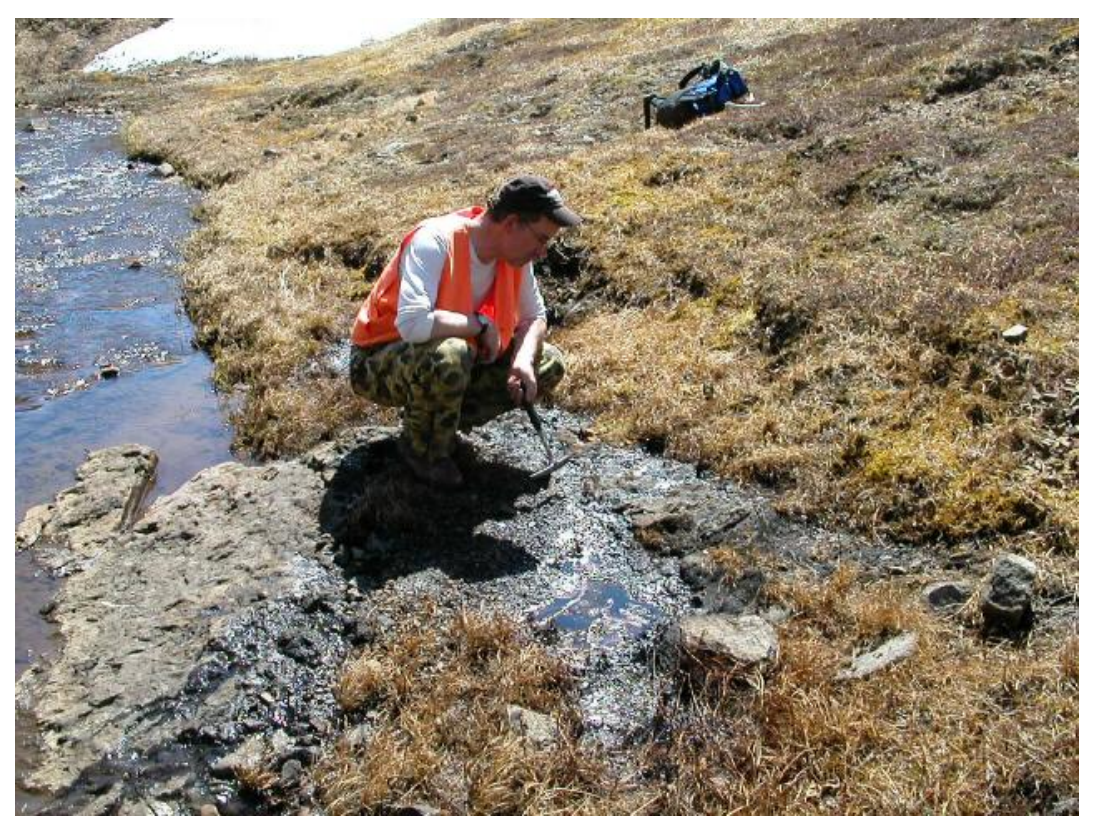

Figure 3. Oil seep issuing from fractured Shelikof Formation outcrop along Oil Creek (location 5 of text). Photo taken May 31, 2004, during visit to site by DGGS field party.

Table 1. Oil and gas seep localities. Coordinates, in many cases, were determined from primitive map bases and thus are often only approximate due to the primitive nature of the earlier topographic maps.

\begin{tabular}{|c|c|c|c|c|}
\hline $\begin{array}{c}\text { Map } \\
\text { Number }\end{array}$ & Latitude & Longitude & Notes & $\begin{array}{c}1: 63,360 \\
\text { Quandrangle }\end{array}$ \\
\hline 1 & 58.0635 & -155.503 & gas seeps & Mt. Katmai A-5 \\
\hline 2 & 57.8898 & -155.478 & gas seep & Karluk D-5 \\
\hline 3 & 57.6985 & -155.752 & oil seep & Karluk C-6 \\
\hline 4 & 57.6980 & -155.751 & oil seep & Karluk C-6 \\
\hline 5 & 57.6965 & -155.747 & oil seep & Karluk C-6 \\
\hline 6 & 57.6411 & -155.835 & oil seep & Karluk C-6 \\
\hline 7 & 57.6349 & -155.908 & oil seep & Karluk C-6 \\
\hline 8 & 57.6307 & -155.903 & gas seep & Karluk C-6 \\
\hline 9 & 57.6077 & -155.936 & oil seep & Karluk C-6 \\
\hline 10 & 57.6172 & -155.948 & oil seep & Karluk C-6 \\
\hline 11 & 57.6635 & -156.310 & oil seep & Ugashik C-1 \\
\hline 12 & 57.6717 & -156.293 & oil seep & Ugashik C-1 \\
\hline 13 & 57.5744 & -156.465 & oil seep & Ugashik C-2 \\
\hline 14 & 57.4305 & -156.305 & solid hydrocarbon & Ugashik B-1 \\
\hline 15 & 57.4027 & -156.352 & oil seep & Ugashik B-2 \\
\hline
\end{tabular}

